\title{
Significance of the Deletion Polymorphism of the Angiotensin Converting Enzyme Gene as a Risk Factor for Myocardial Infarction in Japanese
}

\author{
Yi Zhao, Koichi Higashimori, Jitsuo Higaki, Atsushi Kamitani, \\ Mitsuru Ohishi, Tomohiro Katsuya, Tetsuro Miki, Hiroshi Mikami, \\ Takazo Minamino*, and Toshio Ogihara
}

\begin{abstract}
An association study of the insertion/deletion $(I / D)$ polymorphism of the angiotensin converting enzyme (ACE) gene with myocardial infarction (MI) was performed in middle-aged Japanese men. The $D D$ genotype was significantly more frequent in 101 MI subjects $(0.42)$ than in 102 matched control subjects (0.16) compared with the two other genotypes (IDandII) $(p<0.00005)$. A significant association was observed not only in the low-risk group but also in the high-risk group who were defined according to plasma total cholesterol $\geq 220 \mathrm{mg} / \mathrm{dl}$ and body mass index $\geq 26 \mathrm{~kg} / \mathrm{m}^{2}$. These results indicate that $A C E / D D$ genotype is a potent and important risk factor for MI in Japanese. (Hypertens Res 1994; 17: 55-57)
\end{abstract}

Key Words: myocardial infarction, angiotensin I-converting enzyme, genotype, insertion/deletion polymorphism

Coronary heart disease (CHD)remains a major public health problem in industrialized countries because of its contribution to total mortality. Large international differences in the trends in CHD incidence and mortality have been reported (1). A decline has occurred in the USA, and an increase has been noted in Eastern Europe (2). In Japan, CHDrelated mortality has been decreasing, but the incidence of CHD appears to be gradually increasing. A number of risk factors for coronary atherosclerosis have been well documented based on their relationship to the incidence of CHD in epidemiologic studies. Included among the major risk factors are hyperlipidemia, obesity, hypertension, cigarette smoking, male sex, and diabetes mellitus (3). Recently, one genotype of a polymorphism in the gene for angiotensin converting enzyme (ACE) has been reported to be a new potent risk factor for myocardial infarction (MI) (4).

The ACE gene has been considered as a candidate gene which may contribute to the development of hypertension and cardiovascular diseases. The $287 \mathrm{bp}$ insertion/deletion ( $I / D)$ polymorphism located in intron 16 of the ACE gene has been reported to be associated with marked differences in serum ACE levels in unrelated healthy individuals (5). This apparent association has been noted only in severely hypertensive Caucasians (6), but not in Caucasian offspring in their 20 s with the highest blood pressure for their age group and two hypertensive parents $(7,8)$, nor in Japanese hypertensives (9). Recently, Cambien et al. reported that the $D D$ genotype, which is associated with higher levels of circulating ACE than the ID and $I I$ genotypes, is significantly more frequent in patients with MI than in controls, especially among subjects normally considered to be at low risk (4).

The present report describes an association study of the $I / D$ polymorphism in the gene for ACE with MI in middle-aged Japanese men.

\section{Methods}

Patient selection: The study population consisted of 203 unrelated male Japanese subjects, 65 years of age or younger, from Osaka University Hospital, Sakurabashi-Watanabe Hospital, and Sakuragaoka Hospitel. One-hundred and one of the subjects were patients who had suffered at least one MI during the period from January 1990 through March 1993. All of the patients were diagnosed as having MI by coronary angiography, electrocardiogram criteria, and measurements of heart-specific serum enzymes. One-hundred and two of the matching control subjects were normal volunteers and outpatients at the same 3 hospitals. None had a history of $\mathrm{CHD}$, and all tested normal on electrocardiograms both during rest and physical stress. The mean age

From the Department of Geriatric Medicine, Osaka University Medical School, Osaka, Japan, the ${ }^{*}$ Sakurabashi-Watanabe Hospital, Osaka, Japan.

Address for Reprints: Toshio Ogihara, M.D., Professor of Medicine, Department of Geriatric Medicine, Osaka University Medical School, 2-2 Yamada-oka, Suita, Osaka 565, Japan.

Received August 7, 1993; accepted in revised form October 4, 1993. 
of the patients was 53.6 years (SD 6.8), and that of the controls was 53.5 years (SD 9.2). Informed consent was obtained from the subjects.

Detection of the $I / D$ polymorphism of the ACE gene: DNA was extracted from peripheral blood leukocytes as described previously (10). DNA concentrations were measured by absorbance at 260 $\mathrm{nm}$. Polymerase chain reaction (PCR) was performed according to the method of Rigat et al. (11). The sequence of the sense primer and the antisense primer were 5'-CTGGAGACCACTCCCATCCTTTCT-3' and 5'-GATGTGGCCATCACATTCGTCAGAT-3', respectively. PCR was performed in a final volume of $10 \mu \mathrm{l}$ which contained $20 \mathrm{ng}$ of genomic DNA, 4 pmol of each primer, $200 \mu \mathrm{M}$ each of the four dNTP, $1.5 \mathrm{mM} \mathrm{MgCl}, 20 \mathrm{mM}$ $\mathrm{KCl}, 500 \mu \mathrm{g} / \mathrm{ml}$ bovine serum albumin, $50 \mathrm{mM}$ Tris$\mathrm{HCl}, \mathrm{pH} 8.5$, and 0.3 units of Taq polymerase (Perkin Elmer Cetus, Norwalk, CT, USA). Amplification was carried out in a Gene Amp PCR System 9600 (Perkin Elmer Cetus, Norwalk, CT, USA) for 30 cycles with steps of denaturation at $94^{\circ} \mathrm{C}$ for $60 \mathrm{~s}$, annealing at $55^{\circ} \mathrm{C}$ for $30 \mathrm{~s}$, and extension at $72^{\circ} \mathrm{C}$ for 90s. The PCR products were electrophoresed in $2 \%$ agarose gels, and DNA was visualized directly with ethidium bromide staining.

Statistial analysis: Values are expressed as mean \pm SD. Allele frequencies were deduced from genotype frequencies, and the difference between groups was tested by $\chi^{2}$ analysis with 1 degree of freedom. The significance of the difference in variables of risk factors between the $I / D$ genotypes of the ACE gene was assessed by Student's $t$-test. A value of $p<0.05$ was considered statistically significant.

\section{Results}

PCR allowed the detection of the 287 bp $I / D$ polymorphism of the ACE gene that was evident as a
490 bp fragment (insertion: allele $I$ ) and a $190 \mathrm{bp}$ fragment (deletion: allele $D$ ). Frequencies for $D D$, $I D$, and II genotypes were 42,33 and 26 in the MI subjects, and 16, 44 and 42 in the control subjects, respectively ( $\chi^{2}=17.8, p<0.0002$ ) (Table 1$)$. The $D D$ genotype was significantly more frequent in the MI group than in the control group compared with the two other genotypes (IDand II) $(p<0.00005)$. The odds ratio (an estimate of the relative risk of MI between subjects with the $D D$ genotype and subjects with the $I D$ or $I I$ genotypes) was 3.8 .

All subjects were divided into two groups according to risk status. The low-risk group included subjects with a plasma total cholesterol level lower than $220 \mathrm{mg} / \mathrm{dl}$, those not taking hypolipidaemic drugs, and those with a body mass index $<26$ $\mathrm{kg} / \mathrm{m}^{2}$. In this group, the association between the $D D$ genotype and MI was highly significant $(p<$ 0.0008 ), and the odds ratio was 4.3. Further, even in the high-risk group, which included all subjects who were not in the low-risk group, this association was also statistically significant $(p<0.02)$, and the odds ratio was 3.4 (Table 1).

Several variables, which are considered to be risk factors for MI, were compared between the $I / D$ genotypes of the ACE gene in both the MI and control groups (Table 2). Plasma HDL-cholesterol levels were significantly higher in the control group compared with those in the MI group in $I D$ and $I I$ genotypes. However, no difference could be detected between genotypes in either group. For plasma total cholesterol level, body mass index, and systolic and diastolic blood pressure, there was no difference between genotypes.

\section{Discussion}

The age-adjusted death rates from CHD in Japan are about one-fifth of those in the USA (1). However, recently, with the adaptaion of the cul-

Table 1. Frequencies of ACE genotypes in MI and control subjects

\begin{tabular}{|c|c|c|c|c|c|c|}
\hline & \multicolumn{2}{|c|}{ Total subjects } & \multicolumn{2}{|c|}{ Low-risk group* } & \multicolumn{2}{|c|}{ Hight-risk group ${ }^{* *}$} \\
\hline & MI & Controls & MI & Controls & MI & Controls \\
\hline \multicolumn{7}{|l|}{ Genotypes } \\
\hline$D D$ & 42 & 16 & 26 & 10 & 16 & 6 \\
\hline$I D$ & 33 & 44 & 19 & 19 & 14 & 25 \\
\hline \multirow[t]{2}{*}{ II } & 26 & 42 & 9 & 27 & 17 & 15 \\
\hline & \multicolumn{2}{|c|}{$\chi^{2}=17.8(p<0.0002)$} & \multicolumn{2}{|c|}{$\chi^{2}=16.6(p<0.0003)$} & \multicolumn{2}{|c|}{$\chi^{2}=7.1(p<0.03)$} \\
\hline$D D$ & 42 & 16 & 26 & 10 & 16 & 6 \\
\hline \multirow[t]{2}{*}{$I D+I I$} & 59 & 86 & 28 & 46 & 31 & 40 \\
\hline & \multicolumn{2}{|c|}{$(p<0.00005)$} & \multicolumn{2}{|c|}{$(p<0.0008)$} & \multicolumn{2}{|c|}{$(p<0.02)$} \\
\hline Odds ratio $^{\dagger}$ & \multicolumn{2}{|c|}{3.8} & \multicolumn{2}{|c|}{4.3} & \multicolumn{2}{|c|}{3.4} \\
\hline \multicolumn{7}{|l|}{ Alleles } \\
\hline$D$ & 0.58 & 0.37 & 0.66 & 0.35 & 0.49 & 0.39 \\
\hline \multirow[t]{2}{*}{$I$} & 0.42 & 0.63 & 0.34 & 0.65 & 0.51 & 0.61 \\
\hline & \multicolumn{2}{|c|}{$(p<0.00004)$} & \multicolumn{2}{|c|}{$(p<0.000005)$} & \multicolumn{2}{|c|}{$(p<0.3)$} \\
\hline
\end{tabular}

${ }^{*}$ Subjects with $\mathrm{BMI}<26 \mathrm{~kg} / \mathrm{m}^{2}$, total cholesterol level $<220 \mathrm{mg} / \mathrm{dl}$, and not taking hypolipidemic drugs. ${ }^{* *}$ Subjects not in the low-risk group. ${ }^{\dagger}$ The odds ratio is an estimate of the relative risk of MI between subjects with the $D D$ genotype and subjects with the $I D$ or $I I$ genotype. 
Table 2. Comparison of several variables between $\mathrm{ACE} / \mathrm{ID}$ genotypes in $\mathrm{MI}$ and control subjects

\begin{tabular}{|c|c|c|c|c|c|c|}
\hline \multirow[b]{2}{*}{ ACE genotype } & \multicolumn{3}{|c|}{ MI subjects } & \multicolumn{3}{|c|}{ Control subjects } \\
\hline & $D D$ & $I D$ & II & $D D$ & $I D$ & II \\
\hline Number of subjects & 42 & 33 & 26 & 16 & 44 & 42 \\
\hline Age (y. о.) & $53.8 \pm 5.9$ & $53.2 \pm 6.9$ & $53.8 \pm 7.7$ & $51.0 \pm 10.4$ & $54.4 \pm 8.4$ & $53.5 \pm 9.5$ \\
\hline Total cholesterol (mg/dl) & $209 \pm 26$ & $204 \pm 24$ & $213 \pm 30$ & $182 \pm 50$ & $207 \pm 35$ & $197 \pm 40$ \\
\hline HDL cholesterol (mg/dl) & $39 \pm 11$ & $38 \pm 10$ & $37 \pm 9$ & $43 \pm 18$ & $50 \pm 11^{*}$ & $49 \pm 11^{*}$ \\
\hline $\begin{array}{l}\text { Body mass index } \\
\qquad\left(\mathrm{kg} / \mathrm{m}^{2}\right)\end{array}$ & $24.1 \pm 2.7$ & $24.1 \pm 3.0$ & $24.8 \pm 2.8$ & $23.8 \pm 3.7$ & $24.1 \pm 3.0$ & $23.4 \pm 3.3$ \\
\hline $\begin{array}{l}\text { Systolic blood pressure } \\
\quad(\mathrm{mmHg})\end{array}$ & $134 \pm 21$ & $138 \pm 21$ & $133 \pm 17$ & $139 \pm 19$ & $134 \pm 16$ & $132 \pm 18$ \\
\hline $\begin{array}{l}\text { Diastolic blood pressure } \\
(\mathrm{mmHg})\end{array}$ & $81 \pm 14$ & $83 \pm 15$ & $79 \pm 13$ & $86 \pm 12$ & $85 \pm 9$ & $84 \pm 11$ \\
\hline
\end{tabular}

Values are expressed as mean $\pm \mathrm{SD} .{ }^{*} p<0.001 v s$. MI subjects.

All comparisons are by unpaired $t$-test.

ture of western industrialized countries and the rapid increase in the elderly population, the prevalence of CHD has been gradually increasing, and the management of CHD in view of its risk factors has become one of the important issues for its prevention. Cambien et al. reported that the ACE/DD genotype is a new potent risk factor for MI in middle-aged Caucasian men, particularly in subjects normally considered to be at low-risk, and hypothesized that the mechanism by which the ACE polymorphism affects the risk of $\mathrm{MI}$ is by modulating the level of angiotensin II and bradykinin in the coronary arteries (4). The present study demonstrated that $\mathrm{ACE} / D D$ genotype is significantly more frequent in patients with MI than in controls in middle-aged Japanese men, which confirms the results of Cambien et al. that this $\mathrm{ACE} / D D$ genotype is a new potent risk factor for MI in Japanese, also.

The most interesting finding in this study is that the $D D$ genotype was significantly more frequent in patients with MI even in the high-risk group, in which Cambien et al. could not detect a significant relationship between the ACE/ID polymorphism and MI (4). This difference may be explained by the cultural differences. Among the most obvious cultural differences between Japanese and Caucasians are total calories, fat content of the diet, and the amount of physical work (12). While the Japanese life-style has become more western, the prevalence of severe hyperlipidemia and marked obesity is still relatively low in Japan compared with that in USA and Western Europe. Thus, these risk factors may not constitute such a substantial contribution to the development of coronary arteriosclerosis in Japanese compared with Caucasians. Therefore, the $\mathrm{ACE} / D D$ genotype is significantly related to MI even in the high-risk group. Cultural factors are generally more important than genetic determination of CHD, but this may not apply in the case of Japanese.

In conclusion, the $\mathrm{ACE} / D D$ genotype is a potent and important risk factor for MI in middle-aged Japanese men, not only in low-risk subjects but also in high-risk subjects.

\section{References}

1. Uemura K, Pisa Z: World Health Stat Q 1988; 41 (3/4), 155-178.

2. World Health Organization: World Health Statistics Annual 1990. Geneva, 1991.

3. Ross R: in Hurst JW (ed): The Heart 7th ed. New York, McGraw-Hill, Inc., 1990, pp 877-892.

4. Cambien F, Poirier O, Lecerf L, et al: Deletion polymorphism in the gene for angiotensin-coverting enzyme is a potent risk factor for myocardial infarction. Nature 1992; 359: 641-644.

5. Rigat B, Hubert C, Alhenc-Gelas F, Cambien F, Corvol P, Soubrier F: An insertion/deletion polymorphism in the angiotensin I-converting enzyme gene accounting for half the variance of serum enzyme levels. J Clin Invest 1990; 86: 1343-1346.

6. Zee RYL, Lou YK, Griffiths LR, Morris BJ: Association of a polymorphism of the angiotensin I-converting enzyme gene with essential hypertension. Biochem Biophys Res Commun 1992; 184: 9-15.

7. Harrap SB, Davidson HR, Connor JM, et al: The angiotensin I converting enzyme gene and predisposition to high blood pressure. Hypertension 1993; 21: 455-460.

8. Schmidt S, van Hooft IMS, Grobbee DE, Ganten D, Ritz E: Polymorphism of the angiotensin I converting enzyme gene is apparently not related to high blood pressure: Dutch hypertension and offspring study. $J$ Hypertens 1993; 11: 345-348.

9. Higashimori K, Zhao Y, Higaki J, et al: Association analysis of a polymorphism of the angiotensin converting enzyme gene with essential hypertension in the Japanese population. Biochem Biophys Res Commun 1993; 191: 399-404.

10. Yaoita $\mathrm{Y}$, Honjo $\mathrm{T}$ : Deletion of immunoglobulin heavy chain genes accompanies the class switch rearrangement. Biomed Res 1980; 1: 164-175.

11. Rigat B, Hubert C, Corvol P, Soubrier F: PCR detection of the insertion/deletion polymorphism of the human angiotensin converting enzyme gene. Nucleic Acids Res 1992; 20: 1433.

12. Bierman EL: Atherosclerosis and other forms of arteriosclerosis, in Harrison TR (ed): Principles of Internal Medicine 12th ed. New York, McGraw-Hill, Inc, 1991, pp 992-1001. 